\title{
EVALUASI PENGGUNAAN KOMBINASI OBAT DIGOKSIN DAN FUROSEMID
}

Ine Suharyani*

\begin{abstract}
ABSTRAK
Gagal jantung merupakan kondisi ketika otot jantung sangat lemah sehingga tidak bisa memompa cukup darah keseluruh tubuh dengan tekanan yang tepat. Penelitian ini bertujuan untuk mengetahui ketepatan penggunaan kombinasi digoksin dan furosemid berdasarkan aspek klinis serta pengeluaran kalium dalam tubuh. Penelitian ini dilakukan dengan metode retrospektif yaitu menggunakan data yang telah lalu yang diperoleh dari bagian rekam medik. Data yang diambil adalah resep penggunaan obat kombinasi digoksin dan furosemid yang ada di poli klinik jantung pada periode Oktober - Desember 2014. Hasil penelitian memperlihatkan bahwa 39 resep kombinasi digoksin dan furosemid yang menunjukkan bahwa terdapat $100 \%$ obat berinteraksi, $100 \%$ durasi pemberian obat sesuai dengan literatur, serta $100 \%$ penggunaan dosis sesuai dengan literatur. Hasil pemeriksaan laboratorium kadar elektrolit natrium dalam serum adalah 136 - $145 \mathrm{mEq} / \mathrm{l}$, kadar kalium dalam serum adalah 4,4 - 4,5 mEq/1, serta kadar klorida dalam serum adalah $100-110 \mathrm{mEq} / \mathrm{l}$ yang menunjukkan hasil pemeriksaan laboratorium kadar elektrolit dalam tubuh keadaan normal.
\end{abstract}

Kata kunci : gagal jantung, skrining, digoksin, furosemid

\begin{abstract}
Heart failure is a condition when the heart muscle becomes so weak that it can't pump enough blood throughout the body at the right pressure. The aim of this research to determine the right of combination of digoksin and furosemide seen from clinical aspects as well as the expenditure of potassium in the body. This research is descriptive method. Data collected used retrospective method used the data in the medical record. Prescription drug use a combination of digoxin and furosemide from October to December 2014. The results are 39 recipes combination of digoxin and furosemide which indicate that the drug interacts are $100 \%, 100 \%$ of the right duration of drug delivery, and $100 \%$ are the right dose. Results of electrolyte level in serum sodium is 136-145 $\mathrm{mEq} / \mathrm{L}$, potassium is 4.4 to $4.5 \mathrm{mEq} / \mathrm{l}$ and chloride is $100-110 \mathrm{mEq} / \mathrm{l}$ which shows the electrolytes level in the body at the normal state.
\end{abstract}

Keywords: Heart failure, screening, digoxin, furosemide

\footnotetext{
* Staf Pengajar Akademi Farmasi Muhammadiyah Kuningan
} 


\section{PENDAHULUAN}

Gagal jantung adalah kondisi saat otot jantung menjadi sangat lemah sehingga tidak bisa memompa cukup darah keseluruh tubuh dengan tekanan yang tepat. Di Amerika Serikat lebih dari 4,6 juta pasien yang menderita penyakit ini, dan menjadi penyebab kematian beberapa ratus ribu pasien setiap tahunnya (American Heart Association). ${ }^{1}$

Pasien gagal jantung pada umumnya harus diberikan setidaknya empat jenis obat yaitu, inhibitor ACE (Angiotensin Converting Enzim), diuretik, $\beta$ bloker dan digoksin. Pasien gagal jantung biasanya juga menderita penyakit penyerta lainnya sehingga membutuhkan berbagai macam obat dalam terapinya, ${ }^{2}$ dan tanpa disadari bahwa Interaksi obat yang paling sering terjadi dan harus diwaspadai adalah interaksi antara digoksin dan furosemid yang termasuk golongan diuretik kuat. Furosemid dapat menurunkan volume darah yang bersirkulasi karena dapat menyebabkan pengurangan pada cairan tubuh. Selain itu juga terjadi interaksi yang menyebabkan hipokalemia pada pasien, sehingga keseimbangan air dan elektrolit harus stabil sebelum vasodilator ditambahkan. ${ }^{2}$

Hingga saat ini dokter masih meresepkan obat kombinasi digoksin dan furosemid untuk menangani terapi penyakit gagal jantung, yang sudah jelas akan terjadi interaksi obat di dalam tubuh. Oleh karena itu, penelitian ini dilakukan untuk mengetahui mengapa sampai saat ini dokter masih menggunakan obat kombinasi digoksin dan furosemid.

\section{METODE PENELITIAN}

Pengumpulan data dilakukan menggunakan metode retrospektif dengan menggunakan penelusuran terhadap data di bagian rekam medik, yaitu resep penggunaan obat kombinasi digoksin dan furosemid yang ada di poli klinik jantung di salah satu Rumah Sakit di Kabupaten Kuningan pada Oktober - Desember 2014, kemudian data dianalisis metode deskriptif non analitik.

Populasi pada penelitian ini meliputi resep pasien rawat jalan penderita gagal jantung poli klinik jantung disalah satu Rumah Sakit di Kabupaten Kuningan. Kriteria inklusi sampel yang akan diambil adalah sebagai berikut :

1. Resep dengan penggunaan obat kombinasi digoksin dan furosemid

2. Pasien rawat jalan poli klinik jantung disalah satu Rumah Sakit di Kabupaten Kuningan

3. Data pasien rawat jalan pada periode Oktober - Desember 2014

4. Dosis

5. Diagnosa

6. Hasil pemeriksaan jumlah elektrolit pasien

Analisa data dilakukan dengan cara data yang terkumpul akan diperiksa atau di validasi kemudiaan dilakukan analisis data yang meliputi :

1. Bagaimana skrining resep dilihat dari aspek klinis penggunaan obat kombinasi digoksin dan furosemid?

2. Bagaimana ketepatan penggunaan obat kombinasi digoksin dan furosemid secara klinis ?

3. Berapa jumlah penurunan kalium yang dikeluarkan dari tubuh selama pemberian kombinasi furosemid dan digoksin?

\section{HASIL PENELITIAN}

\section{Pola Peresepan Kombinasi Digoksin Dan Furosemid}

Setelah dilakukan penelitian dibagian rekam medik rawat jalan di salah satu Rumah Sakit di Kabupaten Kuningan, terhadap pasien yang terapi ke poli klinik jantung periode Oktober sampai dengan Desember 2014, didapat 45 sampel pasien yang terapi gagal jantung diberikan pengobatan digoksin dan furosemid, dengan metode pengambilan data secara acak. 
Tabel 1. Jumlah populasi dan sampel resep denganobat kombinasi digoksin dan furosemid

\begin{tabular}{ccc}
\hline Bulan & Jumlah Populasi(lembar) & Jumlah Sampel(lembar) \\
\hline Oktober & 18 & 15 \\
November & 13 & 12 \\
Desember & 14 & 12 \\
\hline Jumlah & 45 & 39 \\
\hline
\end{tabular}

Berdasarkan tabel di atas dapat diketahui jumlah resep yang mengandung obat kombinasi digoksin dan furosemid pada pasien rawat jalan poli klinik jantung di Kabupaten Kuningan periode Oktober - Desember 2014 adalah 45 lembar resep, yaitu 18 resep pada bulan Oktober, 13 resep pada bulan Nopember dan 14 resep pada bulan Desember. Pengambilan sampel resep berdasarkan rumus slovin adalah pada bulan Oktober 15 resep, Nopember 12 resep, dan Desember 12 resep, jadi jumlah sampel resep yang diambil adalah 39 lembar.

\section{Persentasi Jumlah Resep Yang Mengandung Kombinasi Digoksin}

Hasil penelitian menunjukkan persentase penggunaan kombinasi resep digoksin dan furosemid periode Oktober - Desember 2014, dapat dilihat dari grafik dibawah ini:

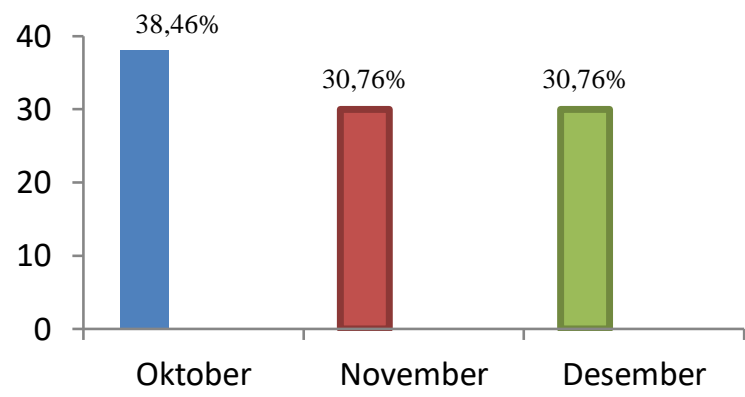

Diagram 1.Grafik Persentase penggunaan obat kombinasi digoksin dan furosemid

Berdasarkan grafik pada diagram 1 terlihat bahwa persentase penggunaan kombinasi digoksin dan furosemid pada pasien rawat jalan poli klinik jantung RSUD 45 Kuningan periode Oktober - Desember 2014, yaitu Oktober (38,46\%), November (30,76\%), Desember $(30,76 \%)$.

\section{Dosis Obat}

Dosis adalah jumlah atau takaran tertentu dari suatu obat yang memberikan efek tertentu terhadap suatu penyakit atau gejala sakit. Jika dosis terlalu rendah (under dose) maka efek terapi tidak tercapai. Berikut adalah tabel persentase hasil skrining klinis secara keseluruhan.

Tabel 4. Persentasi skrining klinis penggunaan kombinasi obat digoksin dan furosemid

\begin{tabular}{|c|c|c|c|c|c|c|c|c|}
\hline \multirow[t]{3}{*}{ Obat } & \multirow[t]{3}{*}{ Jumlah } & \multirow{3}{*}{$\begin{array}{c}\text { Kesesuaian } \\
\text { dengan } \\
\text { Literatur }\end{array}$} & \multicolumn{6}{|c|}{ Skrining Klinis } \\
\hline & & & \multicolumn{2}{|c|}{ Interaksi } & \multicolumn{2}{|c|}{ Durasi } & \multicolumn{2}{|c|}{ Dosis } \\
\hline & & & A & TA & S & TS & $\mathrm{S}$ & TA \\
\hline Digoksin & 39 & $100 \%$ & $100 \%$ & & $100 \%$ & & $100 \%$ & \\
\hline Furosemid & 39 & $100 \%$ & $100 \%$ & & $100 \%$ & & $100 \%$ & \\
\hline Total & 39 & & & & & & & \\
\hline
\end{tabular}

Keterangan : A : Ada interaksi, S : Sesuai dengan literature, TA : Tidak ada Interaksi, TS : Tidak sesuai Literatur 
Berdasarkan tabel 4, total resep untuk digoksin dan furosemid sebanyak 39. Skrining klinis untuk digoksin dan furosemid yang sesuai literatur menunjukkan 100\%, interaksi sebanyak $100 \%$, kesesuaian durasi sebanyak $100 \%$, serta kesesuaian dosis $100 \%$.

\section{Hasil Sebagian Pemeriksaan Laboratorium Elektrolit}

Cairan dan elektrolit sangat diperlukan dalam rangka menjaga kondisi tubuh tetap sehat. Keseimbangan cairan dan elektrolit di dalam tubuh adalah salah satu bagian dari homeostatik. Berikut data sebagian hasil laboratorium elektrolit :

Tabel 5. Data sebagian hasil laboratorium elektrolit

\begin{tabular}{|c|c|c|c|c|c|}
\hline \multirow[t]{2}{*}{ No } & \multirow[t]{2}{*}{ Nama pasien } & \multicolumn{3}{|c|}{ Data Laboratorium Elektrolit } & Elektrolit Normal \\
\hline & & $\mathrm{Na}$ & $\mathrm{K}$ & $\mathrm{Cl}$ & kadar normal natrium dalam \\
\hline 1 & SE & 143 & 4,4 & 110 & serum adalah $136-145 \mathrm{mEq} / 1$ \\
\hline 2 & SU & 136 & 4,4 & 107 & kadar normal kalium dalam \\
\hline 3 & $\mathrm{EC}$ & 136 & 4,4 & 100 & serum adalah $3,5-5,0 \mathrm{mEq} / 1$. \\
\hline 4 & IW & 145 & 4,4 & 107 & Kadar klorida normal dalam \\
\hline 5 & UN & 142 & 4,5 & 110 & serum adalah $95-105 \mathrm{mEq} / \mathrm{l}$. \\
\hline
\end{tabular}

Hasil pemeriksaan kadar natrium rata-rata 136-145 mEq/l. Natrium merupakan kation terbesar yang terdapat dalam cairan ekstraseluler. Kadar natrium dalam serum normalnya adalah 135-145 mEq/l. Untuk kalium rata-rata 4,4 mEq/l di dalam tubuh menunjukan bahwa kalium berada dalam keadaan stabil dan normal kalium dalam serum yaitu 3,5-5,0 mEq/1

\section{Penyakit Penyerta}

Hasil penelitian 74 pasien rawat jalan memperlihatkan bahwa pasien tidak hanya menderita gagal jantung tetapi mempunyai penyakit penyerta seperti yang terlihat pada gambar berikut :

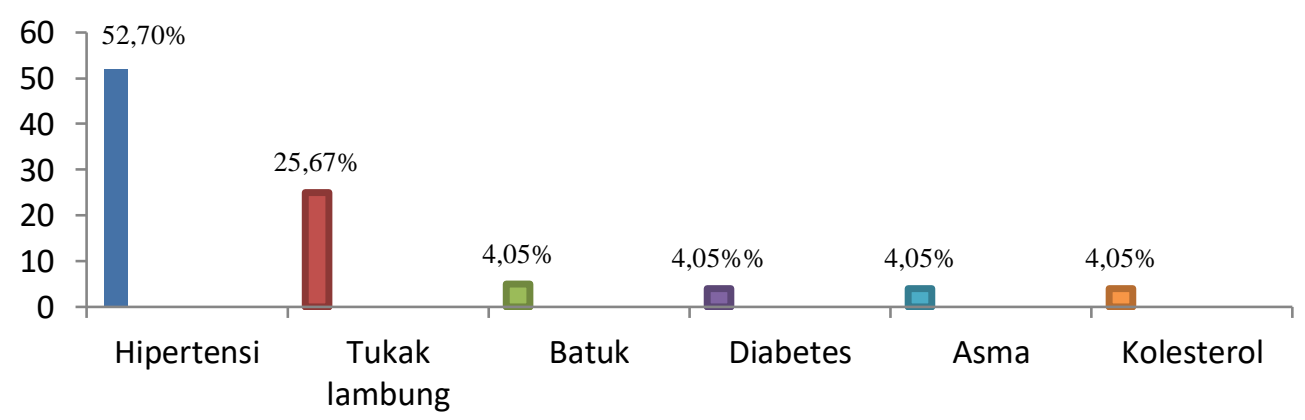

Diagram 2. Grafik penyakit penyerta

Berdasarkan grafik di atas dapat diketahui dari penyakit penyerta gagal jantung yang paling banyak adalah hipertensi (52,70\%), tukak lambung $(25,67 \%)$, batuk $(4,05 \%)$, diabetes $(7,89 \%)$, penyakit diabetes militus merupakan resiko akan terjadinya penyakit gagal jantung, serta asma, kolesterol, dan osteoartritis $(5,26 \%)$. 


\section{PEMBAHASAN}

\section{Indikasi Penggunaan Kombinasi Obat Digoksin Dan Furosemid}

Obat merupakan senyawa yang digunakan untuk mencegah, mengobati, mendiagnosis, penyakit atau gangguan, atau menimbulkam suatu kondisi tertentu. Sedangkan indikasi obat adalah suatu khasiat atau kegunaan dari obat tersebut. Berikut tabel indikasi obat gagal jantung :

Tabel 2. Indikasi Obat

\begin{tabular}{lll}
\hline NO & OBAT & \multicolumn{1}{c}{ INDIKASI } \\
\hline 1 & Digoksin & - Gagal jantung, aritmia supraventrikular (terutama atrial fibrilasi) \\
& & - Payah jantung kongestif, fibrilasi atrium, takikardi atrium proksimal \\
& dan flutter atrium \\
& & - Untuk mengobati gagal jantung kongestif, gangguan irama jantung \\
& & pada atrium \\
& & - Pengobatan udema yang dihubungkan dengan gagal jantung kongestif, \\
& sirosis hati dan penyakit ginjal, termasuk syndrome nefkritis \\
& Furisemid & anti hipertensi \\
& & Suplemen kalium dan magnesium pada penyakit jantung dan penyakit \\
& liver karena hipokalemia dan hipomagnesemia akibat penggunaan dari \\
& Renapar & diuretic \\
&
\end{tabular}

Sumber : ${ }^{4,5}$

Berdasarkan tabel 2, indikasi penggunaan obat kombinasi digoksin, furosemid, dan renapar, diindikasikan untuk penyakit jantung dengan komplikasi penyakit lain.

Kombinasi resep digoksin dan furosemid masih digunakan sebagai terapi pengobatan gagal jantung, sementara secara farmakodinamik jika digoksin dan diuretik loop yaitu furosemid dikombinasikan akan terjadi interaksi yang dapat meningkatkan ekskresi kalium atau hipokalemia dan magnesium sehingga meningkatkan toksisitas digoksin. ${ }^{6}$

Hipokalemia dapat dicegah dengan pemberian suplemen kalium dan magnesium. Kalium dan digitalis berinteraksi dalam dua cara. pertama, keduanya saling menghambat pengikatan $\mathrm{ke} \mathrm{Na}^{+} / \mathrm{K}^{+}$ATPase, dengan demikian, hiperkalemia akan mengurangi kerja glikosida jantung dalam menghambat enzim, sedangkan hipokalemia mempermudah kerja ini. Kedua, automatisasi jantung abnormal dihambat oleh hiperkalemia. Oleh sebab itu, peningkatan $\mathrm{K}^{+}$ ekstraseluler yang sedang akan mengurangi efek digitalis, terutama efek toksik. atau memberikan diuretik hemat kalium seperti spironolakton, kombinasi diuretik loop dengan diuretik hemat kalium memiliki tujuan untuk memblok lebih dari satu tempat dalam nefron secara berurutan sehingga dapat menghasilkan interaksi sinergis antara kedua diuretik tersebut. Digoksin paling sering diresepkan karena sifat farmakokinetiknya yang nyaman, rute pemberian alternatif, dan ketersediaan pengukuran kadar obat dalam serum yang tersebar luas. Sifat farmakokinetik dari diuretik loop yaitu furosemid dapat mempercepat absorpsi dan dieliminasi oleh ginjal melalui filtrasi glomerulus dan sekresi tubulus, sehingga pada pasien rawat jalan yang tidak terlalu gawat diberikan resep kombinasi digoksin dan furosemid untuk mempercepat penurunan oedema dalam tubuh dengan memberikan golongan diuretik loop untuk mengembalikan ritme jantung yang normal. ${ }^{6,7}$

\section{Interaksi Obat}

Interaksi antara obat dan obat adalah peristiwa dimana kerja obat dipengaruhi oleh obat lain yang diberikan bersamaan atau hampir bersamaan, interaksi obat bisa terjadi baik secara farmakokinetik maupun farmakodinamik. Berikut adalah daftar obat interaksinya : 
Tabel 3. Daftar Obat dengan interaksi Farmakodinamik dan Farmakokinetik

\begin{tabular}{|c|c|c|c|}
\hline No & Obat A & Obat B & Mekanisme dan Efek \\
\hline 1. & Furosemid & Digoksin & $\begin{array}{l}\text { Furosemid meningkatkan ekskresi kalium dan } \\
\text { magnesium sehingga meningkatkan toksisitas digoksin }\end{array}$ \\
\hline 2. & Spironolocton & Digoksin & $\begin{array}{l}\text { Spironolakton menghambat sekresi digoksin dan } \\
\text { menurunkan efek hipotensi }\end{array}$ \\
\hline 3. & Bisoprolol & Digoksin & $\begin{array}{l}\text { Bisoprolol menghambat ekskresi digoksin sehingga } \\
\text { menurunkan efek hipotensi }\end{array}$ \\
\hline 4. & Digoksin & Ranitidin & $\begin{array}{l}\text { Ranitidin menyebabkan penurunan kadar digoksin di } \\
\text { dalam darah }\end{array}$ \\
\hline 5. & Furosemid & Simarc & Furosemid dapat meningkatkan aktivitas simarc \\
\hline 6. & Digoksin & Alprazolam & $\begin{array}{l}\text { Alprazolam dapat meningkatkan kadar plasma } \\
\text { digoksin (meningkatkan risiko toksisitas) }\end{array}$ \\
\hline 7. & Digoksin & Sukralfat & $\begin{array}{l}\text { Sukralfat mengurangi absorpsi digoksin sehingga } \\
\text { menurunkan efek hipotensi }\end{array}$ \\
\hline 8. & Furosemid & Aspilet & Menurunkan efek hipotensi \\
\hline 9. & Digoksin & Diltiazem & Diltiazem dapat meningkatkan kadar plasma digoksin \\
\hline 10. & Digoksin & Lansoprazol & $\begin{array}{l}\text { Lansoprazol penghambat pompa proton sehingga } \\
\text { dapat meningkatkan kadar plasma digoksin }\end{array}$ \\
\hline 11. & Digoksin & Antasid & $\begin{array}{l}\text { Antasid mengurangi absorpsi digoksin sehingga } \\
\text { menurunkan efek hipotensi }\end{array}$ \\
\hline
\end{tabular}

Sumber : ${ }^{6,8,9}$

Hasil penelitian yang diambil dari rekam medik dapat dilihat bahwa banyak obat yang berinteraksi baik secara farmakokinetik maupun farmakodinamik. Interaksi obat terjadi apabila dua atau lebih obat berinteraksi sedemikian rupa sehingga ke efektifan atau toksisitas satu atau lebih obat berubah.

Interaksi antara digoksin dan furosemid meningkatkan ekskresi kalium dan magnesium sehingga meningkatkan toksisitas digoksin yang mengakibatkan hipokalemia, untuk terapi pengobatan gagal jantung kombinasi antara digoksin dan furosemid selalu diresepkan karena mekanisme dari keduanya yang sangat cepat terutama pada pasien gagal jantung parah. Hipokalemia dari efek samping kedua obat tersebut dapat dicegah dengan pemberian suplemen kalium dan magnesium atau diuretik hemat kalium. ., $^{8}$

Interaksi secara farmakodinamik yaitu antara spironolakton dan digoksin dapat mengganggu beberapa penetapan kadar digoksin, tetapi dapat juga meningkatkan kadar digoksin dalam darah secara langsung. Pencegahannya adalah pemberian dosis digoksin disesuaikan selama pengobatan berlangsung. Interaksi secara farmakokinetik yaitu antara bisoprolol dengan digoksin dapat menghambat ekskresi digoksin sehingga menurunkan efek hipotensi, selama pengobatan pemberian waktu tenggang sangat penting untuk mencegah terjadinya interaksi tersebut., 6,8

Obat antasida yang mengandung alumunium, sukralfat, dapat menyebabkan penurunan kadar digoksin, hindari waktu penggunaan bersamaan antara digoksin dan sukralfat. Tidak hanya sukralfat, famotidin dan ranitidin juga dapat berinteraksi dengan menyebabkan peningkatan kadar digoksin dalam darah serta memiliki makna klinis. ${ }^{6,8}$

Interaksi dapat terjadi karena pemberian furosemid dengan antikoagulan, jika diberikan bersamaan dapat meningkatkan aktivitas dari antikoagulan. Pemberian waktu tenggang dapat menghindari terjadinya interaksi tersebut. Digoksin dan alprazolam menyebabkan peningkatan kadar plasma digoksin sehingga meningkatkan resiko toksisitas, penggunaan waktu bersamaan harus dihindari karena efek dari salah satu obat tidak akan menghasilkan khasiat yang diinginkan. Dari penelitian yang didapat bahwa furosemid dikombinasikan 
dengan asam asetilsalisilat menyebabkan interaksi tetapi mekanisme kerjanya tidak diketahui, interaksi kedua obat tersebut menyebabkan turunnya efek hipotensi, tetapi tidak ada tindakan yang khusus untuk obat tersebut hanya pemberian waktu tenggang pada saat pemberian obat. Interaksi antara digoksin dan lansoprazol dapat menghambat pompa proton sehingga meningkatkan kadar plasma digoksin, hal ini dapat dicegah dengan pemberian waktu tenggang ketika pemberian. Omeprazol juga menyebabkan penurunan kadar digoksin di dalam darah. Diltiazem juga meningkatkan kadar plasma dari digoksin. Kedua jenis interaksi bisa dihindari dengan memberikan waktu tenggang ketika pemberian obat serta memantau tekanan darah dan menyesuaikan dosis dari furosemid. ${ }^{6,8}$

\section{Durasi Pemakaian Obat}

Durasi adalah waktu yang dibutuhkan untuk setengah dari jumlah awal obat/zat lain dieliminasi dari tubuh. Pada pasien gagal jantung, durasi penggunaan digoksin cukup sehari 1x1, karena obat digoksin kerjanya panjang sehingga efek obatnya dapat bertahan selama 36 jam, waktu paruh eliminasi $30-45$ jam, akumulasi obat dapat terjadi sebab $30 \%$ dari digoksin dimetabolisme oleh hati dan $65 \%$ diekskresikan oleh ginjal. Gangguan fungsi ginjal, fungsi hati dan fungsi tiroid mempengaruhi metabolisme digoksin. Untuk pasien hipotiroidisme, dosis digoksin harus diturunkan, begitu juga sebaliknya. ${ }^{10}$

Penggunaan furosemid sudah sesuai dengan literatur yaitu 1x1 sampai 2 x 1 karena kerjanya cepat, memiliki lama kerja yang lebih pendek $6-8$ jam dan diekskresikan lebih cepat, waktu paruhnya 30 - 50 menit, eliminasi di ginjal $50-75 \%$ tanpa perubahan. ${ }^{10}$

\section{Hasil Sebagian Pemeriksaan Laboratorium Elektrolit}

Cairan dan elektrolit sangat diperlukan dalam rangka menjaga kondisi tubuh tetap sehat. Keseimbangan cairan dan elektrolit di dalam tubuh adalah salah satu bagian dari homeostatik.

Hasil pemeriksaan kadar natrium rata-rata $136-145 \mathrm{mEq} / \mathrm{l}$. Natrium merupakan kation terbesar yang terdapat dalam cairan ekstraseluler. Kadar natrium dalam serum normalnya adalah $135-145 \mathrm{mEq} / \mathrm{l}$. Untuk kalium rata-rata $4,4 \mathrm{mEq} / \mathrm{l}$ di dalam tubuh menunjukan bahwa kalium berada dalam keadaan stabil dan normal kalium dalam serum yaitu 3,5-5,0 mEq/l. Kalium berpengaruh terhadap sebagian sistem tubuh seperti kardiovaskuler. Sementara itu, klorida, yang merupakan anion terbesar dalam cairan ekstraseluler, sangat sedikit ditemukan dalam cairan intrasel. Kadar klorida normal dalam serum adalah 95-105 mEq/1. Hasil pemeriksaan klorida dalam tubuh sesuai dengan literatur yaitu $100-107 \mathrm{mEq} / \mathrm{l}^{7}$

Keseluruhan kadar elektrolit normal, karena selain diberikan resep digoksin dan furosemid juga diberikan suplemen kalium dan diuretik hemat kalium seperti spironolakton. Tetapi dari hasil evaluasi resep yang diberikan kepada pasien banyak obat yang berinteraksi sebab pasien tidak hanya memiliki penyakit gagal jantung, penyakit penyertapun banyak ditemukan sehingga banyak obat yang berinteraksi jika tidak diberikan jeda waktu saat meminum obat. Pemeriksaan elektrolit seharusnya diwajibkan untuk pasien yang diberikan terapi digoksin dan furosemid sebab terapi tersebut berulang setiap bulannya.

Hasil pemeriksaan elektrolit menunjukkan bahwa dosis yang diberikan sudah tepat, sebab bulan sebelumnya pasien diberikan obat yang sama dan bulan berikutnya pasien di cek laboratorium untuk pemeriksaan elektrolit, hasil dari pemeriksaan menunjukan kadar elektrolit dalam tubuh pasien tetap normal.

\section{SIMPULAN}

1. Skrining klinis untuk interaksi obat yang berisi digoksin dan furosemid, di dapat $100 \%$ terbukti adanya interaksi obat merugikan dimana digoksin dengan furosemid dapat menyebabkan hipokalemia, tetapi hipokalemia dapat dicegah dengan pemberian suplemen 
kalium, magnesium untuk menjaga kestabilan elektrolit di dalam tubuh atau dengan pemberian golongan diuretik hemat kalium yaitu spironolakton.

2. Skrining klinis untuk durasi pemakaian $100 \%$ tepat, karena durasi kerja digoksin $36-38$ jam sehingga sehari cukup 1 tablet, sedangkan untuk furosemid durasi pemberian obatnya yaitu $6-8$ jam dimana efek kerjanya yang cepat, memiliki lama kerja yang lebih pendek sehingga dapat digunakan sehari $1-2$ tablet.

3. Skrining klinis untuk dosis obat digoksin dan furosemid $100 \%$ sesuai dengan literatur, untuk dosis digoksin sehari 1 x $0,25 \mathrm{mg}$ pada pasien dengan fungsi ginjal normal, sedangkan dosis untuk furosemid adalah 1 x $40 \mathrm{mg}$ sampai $80 \mathrm{mg}$.

4. Hasil sebagian pemeriksaan elektrolit menunjukkan bahwa kadar natrium dalam serum adalah 136 - $145 \mathrm{mEq} / \mathrm{l}$, kadar kalium dalam serum adalah 4,4 - 4,5 mEq/l, serta kadar klorida dalam serum adalah $100-110 \mathrm{mEq} / \mathrm{l}$ yang menunjukkan hasil pemeriksaan laboratorium kadar elektrolit dalam tubuh keadaan normal.

\section{SARAN}

1. Dokter lebih berhati-hati lagi untuk memberikan kombinasi digoksin dan furosemid untuk menangani penyakit jantung karena akan terjadi interaksi obat disamping, pasien yang ditangani memiliki penyakit penyerta sehingga harus diperhatikan jeda waktu yang tepat untuk meminum obat

2. Dokter bekerjasama dengan pihak rumah sakit untuk mewajibkan melakukan pemeriksaan elektrolit karena terapi yang diberikan berulang setiap bulannya

\section{DAFTAR PUSTAKA}

1. Priyanto. Farmakologi dasar untuk mahasiswa farmasi dan perawat. Edisi kedua:Jakarta; 2008

2. Surabaya, Universitas. Farmasi klinik. Edisi Kesatu. Jakarta: PT.Elex media Komputindo; 2003

3. Sevilla, Consuelo G. et. al. Research Methods. Quezon City: Rex Printing Company; 2007

4. Katzung, Bertram. Farmakologi dasar dan klinik. Edisi sepuluh. Jakarta: EGC; 2009

5. Badan Pengawas Obat dan Makanan Republik Indonesia. Informatorium obat nasional Indonesia 2008. Jakarta: POM RI; 2009

6. Baxter. Stocley's Drug Interactions, eighth edition, London : London pharmaceutical press; 2008

7. Tamsuri, Anas. Klien gangguan keseimbangan cairan dan elektrolit seri asuhan keperawatan. Edisi pertama. Jakarta: EGC; 2009

8. Thanacoody. Drug interactions and therapeutics. Fifth edition. London: Churchill livingstone Elsevier; 2012

9. Lancy, Charles. Drug information handbook, Eighteen Edition, America: America pharmacist association; 2009

10. Mozayani, Ashraf. Interaksi obat pedoman klinis dan forensik. Edisi Ketiga. Jakarta: EGC; 2013 